\title{
Investigation of Outdoor Gamma Dose Rates in Yalova, Turkey
}

\author{
Kübra Bayrak ${ }^{1}$, Zeki Ünal Yümün ${ }^{2 *}$, Merve Çakar ${ }^{3}$ \\ ${ }^{1}$ Akdeniz University, Faculty of Science, Physics Department, Antalya, Turkey \\ ${ }^{2}$ Namik Kemal University, Corlu Engineering Faculty, Environmental Engineering Dep., Tekirdag, Turkey \\ ${ }^{3}$ yildiz Technical University, Faculty of Arts And Sciences, Physics Department, Davutpasa Campus, 34220 Esenler, Istanbul, Turkey
}

(First received 8 February 2020 and in final form 17 March 2020)

(DOI: $10.31590 /$ ejosat.686668)

\begin{abstract}
ATIF/REFERENCE: Bayrak, K., Yümün, Z. Ü. \& Çakar, M. (2020). Investigation of Outdoor Gamma Dose Rates in Yalova,
\end{abstract} Turkey. European Journal of Science and Technology, (18), 568-573.

\begin{abstract}
Radioactivity measurements were performed, at the Yalova (Turkey), part of the Marmara Sea, for natural radiation using a scintillation detector SP6 (via using portable counter ESP2, Eberline). Based on the measurement results, the lowest outdoor gamma concentration was calculated to $27.70 \mathrm{nGy} / \mathrm{h}$ while the highest one calculated to $66.00 \mathrm{nGy} / \mathrm{h}$. And, the average of the measured gamma dose rates calculated to $48.13 \mathrm{nGy} / \mathrm{h}$ while the annual effective dose equivalent was calculated to $59.02 \mu \mathrm{Sv} / \mathrm{y}$. Mean value of excess lifetime cancer risk also obtained $2.0710^{-4}$ from using measurement area. The results checked against the world average determined by UNSCEAR. It was concluded that the calculated gamma dose values in Yalova are below the world average.
\end{abstract}

Keywords: Gamma dose rates, Scintillation detector, Yalova, Turkey

\section{Introduction}

The world is in interaction with radiation since its existence. Mankind lives with background radiation originate from radioactive atoms. For this reason, people are always exposed to radioactive substances from air, water, soil and cosmic rays. In addition, with the rapid development of the nuclear industry, the usage of radioactive materials has become widespread [1]. Natural background radiation levels may vary greatly from one location to another as well as may change over the same location over time.

Today, environmental radiation measurements are made in order to survey the radioactivity of a region. By measuring natural background radiation, it is possible to show how much radiation people are exposed to. The level of background radiation of a region varies depending on the geological and geographical structure of the region, the altitude from sea level (proportional to cosmic rays), and the mineralogical structure of the soil and rocks. Nuclear weapons tests, leaks of nuclear power plant accidents and radioactive materials used in the industry and medicine increase the level of natural background radiation of a zone [2].

Kam et.al (2016) conducted the study "Gamma dose rate values in the Kulakçayırı natural lake and the vicinity (Arnavutköy, Istanbul)". In the study, he performed gamma dose measurements at twenty locations in Kulakçayırı and its surroundings. As a result of this measurement, the average gamma dose rate was calculated as $37.5 \mathrm{nGy} / \mathrm{h}$ (19). Yümün et.al (2019) conducted the study "Gamma dose values of stratigraphic units surfaced in Behramkale (Çanakkale) - Zeytinli (Edremit-Balıkesir) section of Kaz Mountains". In the study, gamma dose rate was measured in twenty-five locations around Edremit and Behramkale. The calculated average gamma dose rate was $111.2 \mathrm{nGy} / \mathrm{y}$, and the effective gamma dose value was determined as $0.14 \mathrm{mSV}$ (20). Karataşli M. (2018), "Environmental Gamma Radiation Measurement in Hatay and Its Surroundings" study, measurements were taken at 183 different points. As a result of the measurements, the mean value of gamma dose measurements was calculated as $61.9 \mathrm{nGy} / \mathrm{h}$, while the average value of the annual effective dose equivalent was calculated as 75.91 MSv / y (21).

In this study, the natural background radiation level of Yalova region has been revealed. Many points of the study area were evaluated by measuring gamma doses with a scintillation detector.

\footnotetext{
* Corresponding Author: Namik Kemal University, Corlu Engineering Faculty, Environmental Engineering Dep., Tekirdag, Turkey, zyumun@nku.edu.tr 


\section{Material Method}

\subsection{Measuring Area}

Yalova province is located at the entrance of Izmit bay in the Marmara Sea. As seen in Figure 1, Yalova territory is bordered by the province of Marmara Sea, the province of Kocaeli to the east and the province of Bursa to the southwest [3]. The working area is divided into 6 districts: Altionova, Armutlu, Çiftlikköy, Çınarcık, Termal and Yalova [4]. Based on TÜİK datas, the city's population has been rising continuously for years. Yalova, a tourism city, has been invested in industry, transportation, agriculture and many other areas and these investments are continuing consistently $[5,6]$.

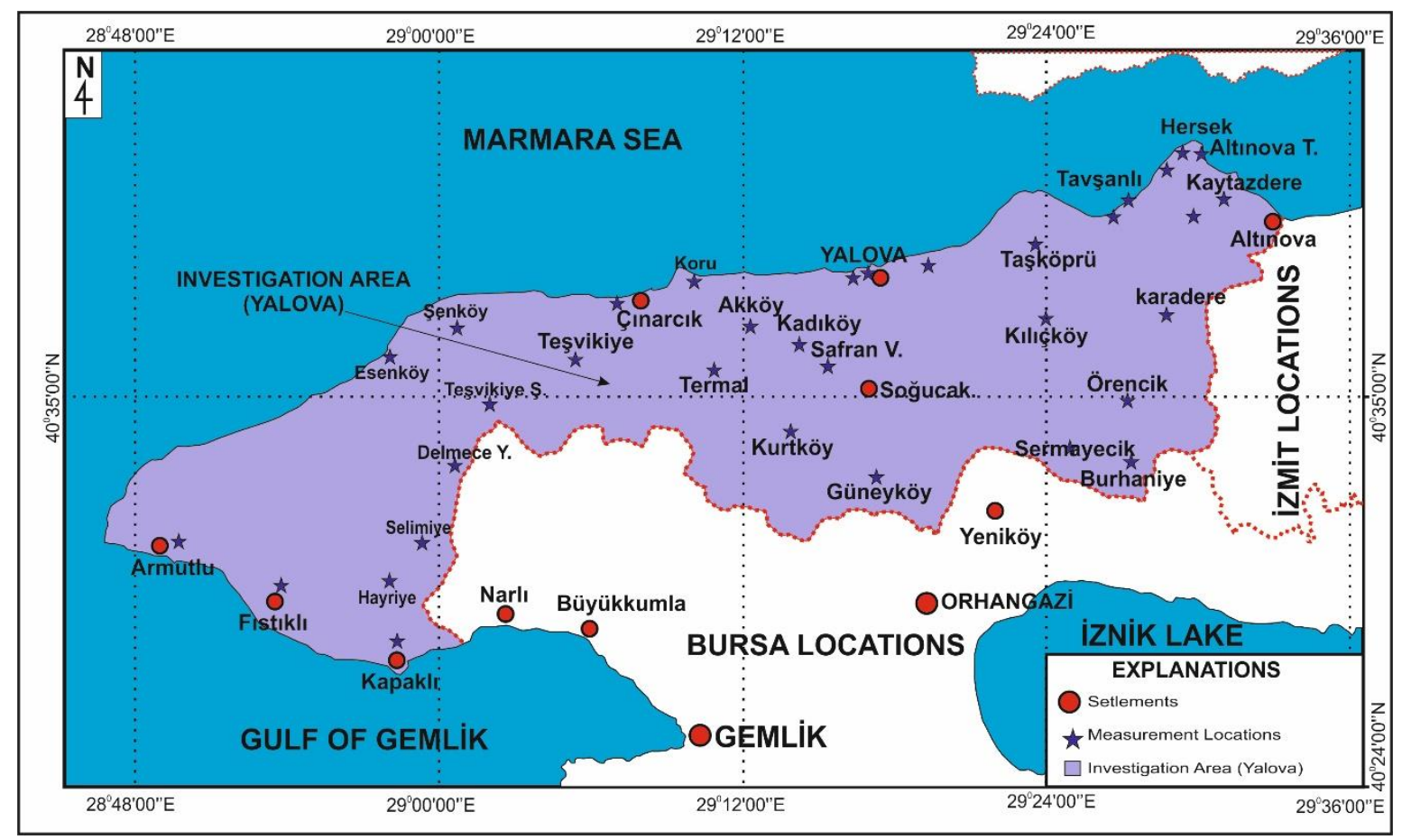

Figure 1: Map of investigation area ()

\subsection{Process}

The device used in the study is a scintillation detector. Scintillation detectors are highly efficient for gamma ray detection. A portable gamma-ray spectrometer is a crucial tool for radionuclide identification in environmental surveying and many other scientific and industrial applications. In environmental measurements, detectors collect radioactive data from the air and analyze simultaneously. The ability to take quick measurements, compact size and low cost are the most precious features of portable devices [7]. In this study, outdoor gamma dose rates were measured by a high resolution Eberline smart portable device (ESP-2). All measurements were taken $1 \mathrm{~m}$ above ground level. And, the measurement duration was roughly one minute for each station. After gamma dose rates were measured, the equivalent dose rate expected to be taken annually by a person was calculated. In this way, the average annual effective dose equivalent (AEDE) was calculated by using the following equation:

$\mathrm{AEDE}=\mathrm{ADRA} \times \mathrm{DCF} \times \mathrm{OF} \times \mathrm{T}$

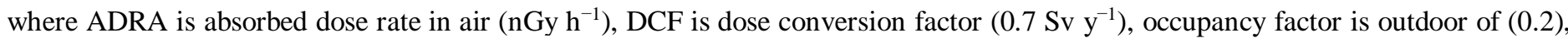
and $\mathrm{T}$ is the time $\left(8760 \mathrm{hy}^{-1}\right)$ [8,16,17]. Excess Lifetime canser Risk was calculated by using following equation [9]:

$\mathrm{ELCR}=\mathrm{AEDE} * \mathrm{DL} * \mathrm{RF}$

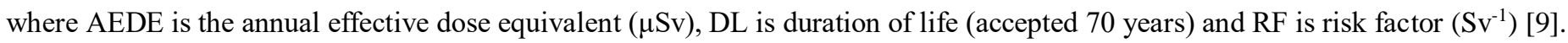

\section{Results}

\subsection{Gamma Dose Measurements}

Within the scope of the study, 36 gamma dose measurements from different stations were taken from the districts of Yalova province. The measured absorbed dose rates and calculated AEDE and ELCR values are given in Table I. 
Table I: Gamma dose rates of Yalova districts

\begin{tabular}{|c|c|c|c|c|c|}
\hline Stations & \multicolumn{2}{|c|}{ Coordinates } & \multirow{2}{*}{$\begin{array}{c}\begin{array}{c}\text { Absorbed } \\
\text { Dose Rate } \\
\text { (nGy/h) }\end{array} \\
52.20\end{array}$} & \multirow{2}{*}{$\begin{array}{c}\text { Annual } \\
\text { Effective } \\
\text { Dose } \\
\text { Equivalent } \\
(\boldsymbol{\mu S v} / \mathbf{y}) \\
64.02\end{array}$} & \multirow{2}{*}{$\begin{array}{c}\text { Excess } \\
\text { Lifetime } \\
\text { Cancer Risk } \\
\left(* \mathbf{1 0}^{-\mathbf{4}}\right) \\
2.24\end{array}$} \\
\hline Kaytazdere & $40^{\circ} 41^{\prime} 49.7^{\prime \prime} \mathrm{N}$ & $29^{\circ} 30^{\prime} 58.6^{\prime \prime} E$ & & & \\
\hline Hersek & $40^{\circ} 43^{\prime} 26.4^{\prime \prime} N$ & $29^{\circ} 30^{\prime} 17.2^{\prime \prime} E$ & 64.00 & 78.49 & 2.75 \\
\hline Karadere & $40^{\circ} 38^{\prime} 12.3^{\prime \prime} N$ & $29^{\circ} 28^{\prime} 23.5^{\prime \prime} E$ & 59.40 & 72.85 & 2.55 \\
\hline Örencik & $40^{\circ} 35^{\prime} 34.2^{\prime \prime} \mathrm{N}$ & $29^{\circ} 26^{\prime} 38.8^{\prime \prime} E$ & 37.80 & 46.36 & 1.62 \\
\hline Sermayecik & $40^{\circ} 33^{\prime} 42.8^{\prime \prime} \mathrm{N}$ & $29^{\circ} 26^{\prime} 37.3^{\prime \prime} E$ & 40.80 & 50.04 & 1.75 \\
\hline Burhaniye & $40^{\circ} 34^{\prime} 07.3^{\prime \prime} \mathrm{N}$ & $29^{\circ} 24^{\prime} 11.2^{\prime \prime} E$ & 43.40 & 53.23 & 1.86 \\
\hline Kılıçköy & $40^{\circ} 38^{\prime} 03.6^{\prime \prime} \mathrm{N}$ & $29^{\circ} 23^{\prime} 36.7^{\prime \prime} E$ & 66.00 & 80.94 & 2.83 \\
\hline Taşköprü & $40^{\circ} 40^{\prime} 28.1^{\prime \prime} \mathrm{N}$ & $29^{\circ} 23^{\prime} 21.1^{\prime \prime} E$ & 56.20 & 68.92 & 2.41 \\
\hline Çiftlikköy & $40^{\circ} 39^{\prime} 45.2^{\prime \prime} \mathrm{N}$ & $29^{\circ} 18^{\prime} 47.7^{\prime \prime} E$ & 51.40 & 63.04 & 2.21 \\
\hline Yalova Merkez & $40^{\circ} 39^{\prime} 27.4^{\prime \prime} N$ & $29^{\circ} 16^{\prime} 06.5^{\prime \prime} E$ & 40.80 & 50.04 & 1.75 \\
\hline Yalova Merkez & $40^{\circ} 39^{\prime} 31.1^{\prime \prime} \mathrm{N}$ & $29^{\circ} 16^{\prime} 31.1^{\prime \prime} E$ & 27.70 & 33.97 & 1.19 \\
\hline Safran Köyü & $40^{\circ} 36^{\prime} 33.4^{\prime \prime} N$ & $29^{\circ} 14^{\prime} 54.7^{\prime \prime} E$ & 40.80 & 50.04 & 1.75 \\
\hline Güneyköy & $40^{\circ} 33^{\prime} 13.9^{\prime \prime} \mathrm{N}$ & $29^{\circ} 16^{\prime} 41.1^{\prime \prime} E$ & 47.00 & 57.64 & 2.02 \\
\hline Kurtköy & $40^{\circ} 34^{\prime} 35.1^{\prime \prime} \mathrm{N}$ & $29^{\circ} 13^{\prime} 25.1^{\prime \prime} E$ & 44.40 & 54.45 & 1.91 \\
\hline Kadıköy & $40^{\circ} 37^{\prime} 09.6^{\prime \prime} \mathrm{N}$ & $29^{\circ} 13^{\prime} 32.1^{\prime \prime} E$ & 60.40 & 74.07 & 2.59 \\
\hline Termal & $40^{\circ} 36^{\prime} 23.1^{\prime \prime} \mathrm{N}$ & $29^{\circ} 10^{\prime} 22.9^{\prime \prime} \mathrm{E}$ & 50.80 & 62.30 & 2.18 \\
\hline Akköy & $40^{\circ} 37^{\prime} 43.0^{\prime \prime} \mathrm{N}$ & $29^{\circ} 11^{\prime} 44.9^{\prime \prime} E$ & 46.52 & 57.05 & 2.00 \\
\hline Koru & $40^{\circ} 39^{\prime} 18.9^{\prime \prime} \mathrm{N}$ & $29^{\circ} 09^{\prime} 26.6^{\prime \prime} E$ & 38.20 & 46.85 & 1.64 \\
\hline Çınarcık & $40^{\circ} 38^{\prime} 36.7^{\prime \prime} \mathrm{N}$ & $29^{\circ} 06^{\prime} 24.6^{\prime \prime} E$ & 44.60 & 54.70 & 1.91 \\
\hline Şenköy & $40^{\circ} 37^{\prime} 39.1^{\prime \prime} \mathrm{N}$ & $29^{\circ} 00^{\prime} 06.7^{\prime \prime} E$ & 64.00 & 78.49 & 2.75 \\
\hline Teşvikiye & $40^{\circ} 36^{\prime} 42.1^{\prime \prime} \mathrm{N}$ & $29^{\circ} 04^{\prime} 54.7^{\prime \prime} E$ & 43.60 & 53.47 & 1.87 \\
\hline Teşvikiye Şelale & $40^{\circ} 35^{\prime} 17.6^{\prime \prime} \mathrm{N}$ & $29^{\circ} 01^{\prime} 34.9^{\prime \prime} E$ & 57.00 & 69.90 & 2.45 \\
\hline Esenköy & $40^{\circ} 36^{\prime} 49.1^{\prime \prime} \mathrm{N}$ & $28^{\circ} 57^{\prime} 10.9^{\prime \prime} E$ & 47.00 & 57.64 & 2.02 \\
\hline Armutlu & $40^{\circ} 31^{\prime} 09.1^{\prime \prime} \mathrm{N}$ & $28^{\circ} 49^{\prime} 41.6^{\prime \prime} E$ & 35.40 & 43.41 & 1.52 \\
\hline Fist1kl1 & $40^{\circ} 29^{\prime} 27.6^{\prime \prime} \mathrm{N}$ & $28^{\circ} 53^{\prime} 34.0^{\prime \prime} \mathrm{E}$ & 56.20 & 68.92 & 2.41 \\
\hline Kapaklı & $40^{\circ} 27^{\prime} 38.0^{\prime \prime} \mathrm{N}$ & $28^{\circ} 58^{\prime} 12.2^{\prime \prime} E$ & 46.80 & 57.40 & 2.01 \\
\hline Hayriye & $40^{\circ} 30^{\prime} 05.3^{\prime \prime} N$ & $28^{\circ} 58^{\prime} 04.6^{\prime \prime} E$ & 41.10 & 50.40 & 1.76 \\
\hline Selimiye & $40^{\circ} 31^{\prime} 03.1^{\prime \prime} \mathrm{N}$ & $28^{\circ} 58^{\prime} 57.6^{\prime \prime} E$ & 47.01 & 57.61 & 2.02 \\
\hline Delmece Yaylası & $40^{\circ} 33^{\prime} 25.8^{\prime \prime} N$ & $29^{\circ} 00^{\prime} 22.9^{\prime \prime} E$ & 52.40 & 64.30 & 2.25 \\
\hline Altınova Merkez & $40^{\circ} 41^{\prime} 19.5^{\prime \prime} \mathrm{N}$ & $29^{\circ} 29^{\prime} 49.7^{\prime \prime} E$ & 59.01 & 72.40 & 2.53 \\
\hline Tavşanlı & $40^{\circ} 41^{\prime} 42.2^{\prime \prime} \mathrm{N}$ & $29^{\circ} 27^{\prime} 14.1^{\prime \prime} E$ & 40.80 & 50.03 & 1.75 \\
\hline Tavşanlı & $40^{\circ} 41^{\prime} 32.2^{\prime \prime} \mathrm{N}$ & $29^{\circ} 26^{\prime} 46.1^{\prime \prime} E$ & 43.60 & 53.50 & 1.87 \\
\hline Tavşanlı & $40^{\circ} 41^{\prime} 14.3^{\prime \prime} \mathrm{N}$ & $29^{\circ} 26^{\prime} 36.3^{\prime \prime} E$ & 54.40 & 66.71 & 2.34 \\
\hline Altınova Tersaneler & $40^{\circ} 43^{\prime} 15.4^{\prime \prime} \mathrm{N}$ & $29^{\circ} 29^{\prime} 16.0^{\prime \prime} E$ & 55.80 & 68.40 & 2.40 \\
\hline Altınova Tersaneler & $40^{\circ} 42^{\prime} 53.0^{\prime \prime} \mathrm{N}$ & $29^{\circ} 28^{\prime} 42.2^{\prime \prime} E$ & 38.20 & 46.81 & 1.64 \\
\hline Altınova Tersaneler & $40^{\circ} 42^{\prime} 05.0^{\prime \prime} \mathrm{N}$ & $29^{\circ} 28^{\prime} 04.1^{\prime \prime} E$ & 37.80 & 46.40 & 1.62 \\
\hline AVERAGE & & & 48.13 & $\mathbf{5 9 . 0 2}$ & 2.07 \\
\hline
\end{tabular}

As a result of the measurements, outdoor gamma dose rates in air are ranging from $27.70 \mathrm{nGy} / \mathrm{h}$ to $66.00 \mathrm{nGy} / \mathrm{h}$. The mean value of gamma dose rate was obtained to $48.13 \mathrm{nGy} / \mathrm{h}$. Next, the average annual effective dose equivalent of 36 stations was calculated to $59.02 \mu \mathrm{Sv}$. Using this data, the lifetime cancer risk was calculated to $2.07\left(* 10^{-4}\right)$. In the light of the data in Table 1 , AEDE values of six districts of Yalova are shown in Figure 2. 


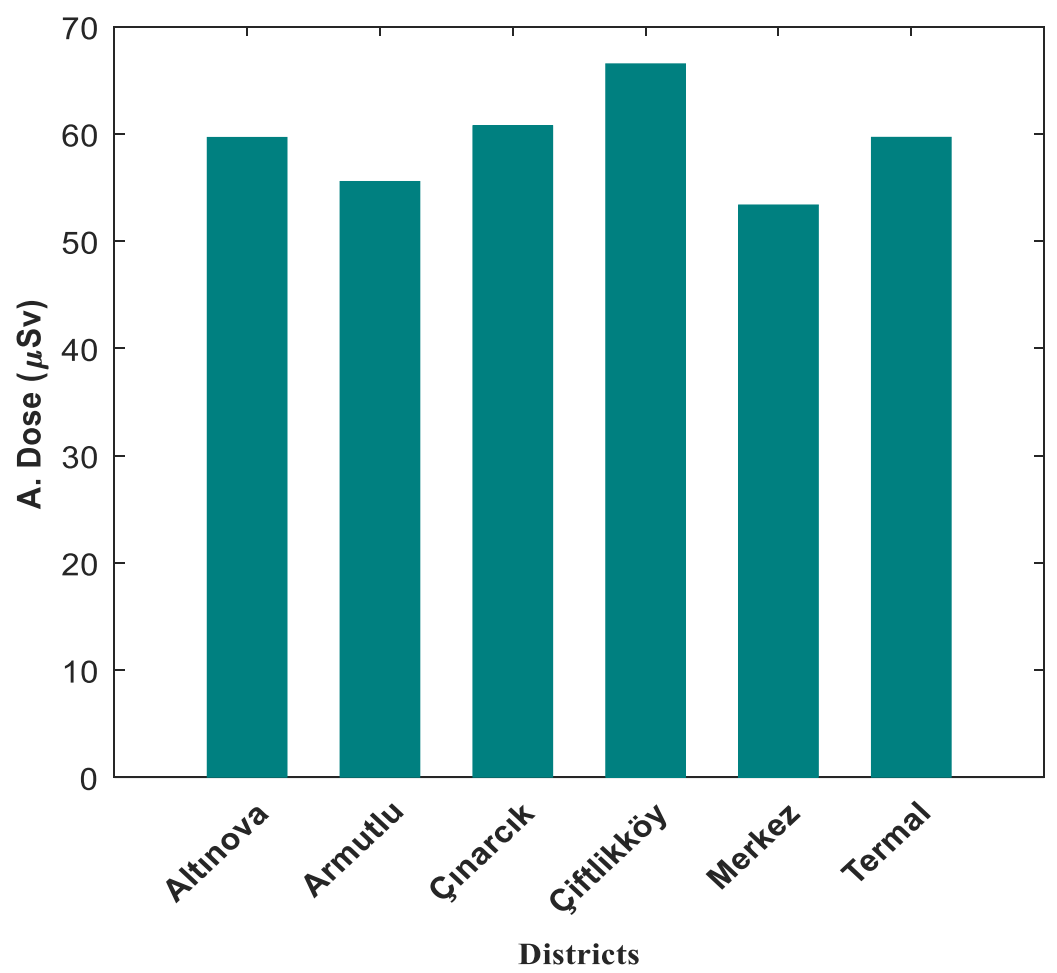

Figure 2. Bar chart of annual doses

The gamma dose distribution map of the districts of Yalova province has been prepared (Figure 3)

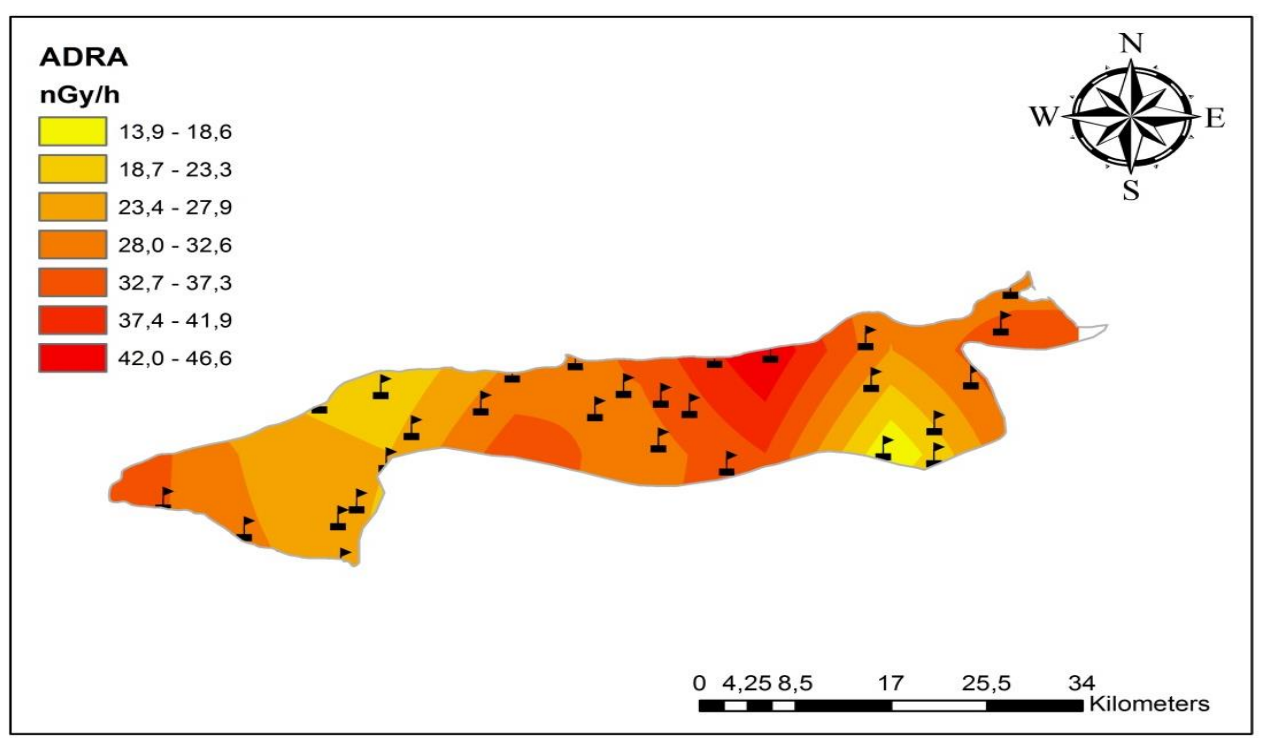

Figure 3: Distribution map of ADRA values by region

As seen in Figure 2 and Figure 3, it is understood that the region with the highest radioactive contamination is Çiftlikköy. However, there is not a crucial difference between other districts about average doses. This study was compared with studies conducted on different regions in Turkey (Table II). the number of references should be increased. 
Avrupa Bilim ve Teknoloji Dergisi

Table II: Gamma dose values of different stations in Turkey

\begin{tabular}{lccc}
\hline Stations & $\begin{array}{c}\text { Average Dose } \\
\text { Rates }(\mathbf{n G y} / \mathbf{h})\end{array}$ & $\begin{array}{c}\text { Average AEDE } \\
(\boldsymbol{\mu S v} / \mathbf{y})\end{array}$ & References \\
\hline Istanbul (2000) & 65 & 80 & {$[10]$} \\
Kirklareli (2009) & 118 & 144 & {$[8]$} \\
Kastamonu (2007) & 48 & 58.9 & {$[11]$} \\
Tekirdag (2005) & 43 & 52.7 & {$[12]$} \\
Hatay (2015) & 52.13 & 63.93 & {$[13]$} \\
IDA villages (2019) & 162.04 & 198.66 & {$[14]$} \\
World average & 59 & 73.6 & {$[15]$} \\
Present Study & 48.13 & 59.02 & - \\
\hline
\end{tabular}

\subsection{Relationship Between Geology and Gamma Dose}

Geological formations of Yalova have been obtained from Turkey's 1/500000 scale geological maps . This map was prepared by the General Directorate of Mineral Research and Exploration (Figure 4).

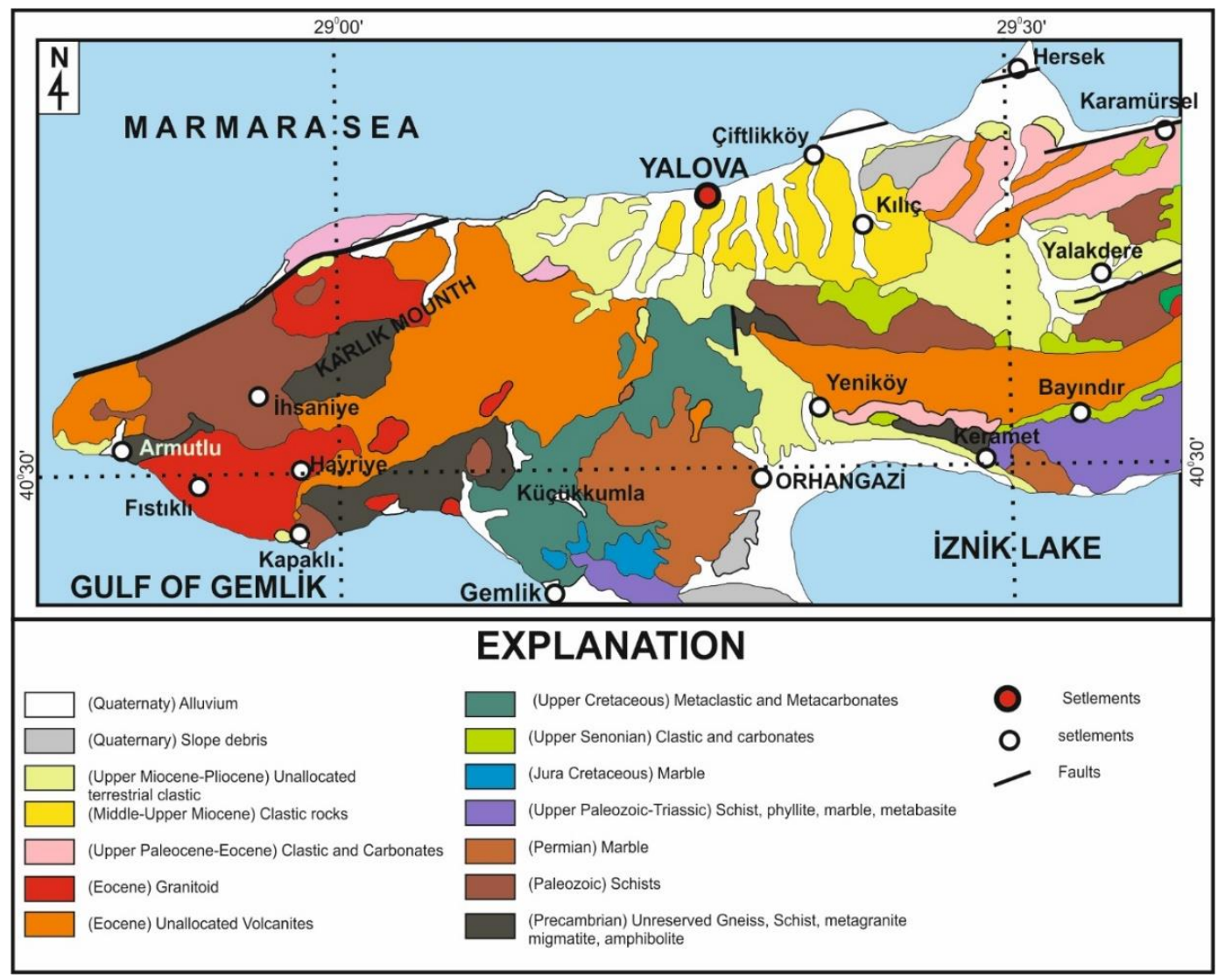

Figure 4: Geology map of Yalova and Surroundings (18)

In the study area, there are Precambrian, Paleozoic, Mesozoic and Cenozoic units from bottom to top. Precambrian units are unallocated gneiss, schist, metagranite, migmatite and amphibolites. Paleozoic units are Schists, marbles and Upper Permian-Triassic schist, phyllite, marble and metabasites. Mesozoic Units are Jurassic marbles, Upper Senonian Clastic rocks and carbonates, and Upper Cretaceous metaclastic and metacarbonates. Cenozoic units consists of Eocene and Paleocene rocks. Eocene consists of undivided volcanites and granitoid. Upper Paleocene-Eocene Unites are clastic rocks and carbonates, and Upper Miocene-Pliocene unites also consist of undivided continental sediments. All units are unconformably covered from quaternary alluvium and slope debris.

\section{Conclusion}

In this study, gamma dose rates of the Yalova were determined. A total of 36 measurements were taken with a scintillation detector. As a result of the measurements, average gamma dose rate and average AEDE value was calculated to $48.13 \mathrm{nGy} / \mathrm{h}$ and $59.02 \mu \mathrm{Sv} / \mathrm{y}$, respectively. And, average axcess lifetime cancer risk was calculated to $2.0710^{-4}$. These values are low compared to many other 
regions. Also, it was observed that the measured gamma dose values were below the world average. In conclusion, there is no health risk related to outdoor gamma radiation of living beings in the region.

In Section 3.2, geological formations of yalova and its surroundings are evaluated. There are rocks of all periods from the oldest to the youngest in the field. Both magmatic, metamorphic and sedimentary rocks can be seen in the region. It is seen that gamma dose values in the region are independent from geological formations. Contrary to the knowledge that gamma dose values may be high in granitoids, gamma dose values do not differ much between lithologies.

\section{References}

[1] UNSCEAR. (2008). Sources and effects of Ionising Radiation, pp 5-6

[2] IAEA (2011). Radioactive Particles in the Environment: Sources, Particle Characterization and Analytical Techniques. pp. 8-10

[3] http://yerbilimleri.mta.gov.tr/anasayfa.aspx

[4] Kazel E. (2014). Yalova City Geography. Master Thesis.

[5] http://www.yalova.bel.tr/kent-rehberi/yalova-hakkinda

[6] https://biruni.tuik.gov.tr/medas/?kn=95\&locale=tr

[7] Nguyen Duc Tuan et all. (2012). Design and construction of the portable gamma-ray spectrometer for environmental dose rate measurement and radioisotope identification

[8] Taskin H. (2009). Radionuclide concentrations in soil and lifetime cancer risk due to gamma radioactivity in Kirklareli, Turkey. 100 (2009) 49-53

[9] ICRP., ICRP Publication 103 recommendations of the ICRP: annals of the ICRP volume 37/2-4. International Commission on Radiological Protection. Pergamon Pres, 2007.

[10] Karahan G. (2000). Assessment of gamma dose rates around Istanbul (Turkey). 47 (2000) 213-221

[11] Kam E. (2007). Environmental radioactivity measurements in Kastamonu region of northern Turkey. 65 (2007) 440-444

[12] Yarar Y. (2005). Environmental radioactivity concentrations of Tekirdag. 1276 (2005) 387-389

[13] Turgay M.E. (2015). Assessment of the Environmental Radioactivity in Hatay Region. University of Gaziantep Graduate School of Natural \& Applied Sciences. Ph.D. Thesis

[14]Turgay, M. E. (2019). Cancer Risk Determination for IDA villages by using Annual Gamma Doses in Air, around Edremit \& Ayvacık Districts; Balıkesir \& Çanakkale, TURKEY. European Journal of Science and Technology, (15), 433-439.

[15] UNSCEAR report. (2000). Sources and Effects of Ionising Radiation pp. 90

[16] Yümün Z.Ü., Kam E., Önce M. (2019). Gamma Dose Values of Stratigraphic Units Surfaced in Behramkale (Çanakkale)-Zeytinli (Edremit - Balıkesir) Section of KazMountains. Journal of the Turkish Chemical Society Section A: Chemistry. 7(1). 207-214.

[17]Kam E., Yümün Z.Ü., Önce M., Açıgöz G. (2016). Gamma Dose Rate Values in the Kulakçayırı Natural Lake and the Vicinity (Aravutköy, İstanbul). Journal of Engineering Technology and Applied Sciences. 1(1). 29-33.

[18]Türkecan, A. and Yurtsever, A., 2002, 1:500.000 Scale Geological Maps of Turkey (İstanbul Map), General Directorate of Mieral Research and Explanation, No.1.

[19]Kam E., Yümün Z.Ü., Önce M. Ve Açıkgöz G. (2016). Gamma dose rate values in the Kulakçayırı natural lake and the vicinity (Arnavutköy, İstanbul). Journal of Engineering Technology and Applied Sciences. 1(1). 29-33.

[20]Yümün Z.Ü., Kam E. ve Önce M.(2019). Gamma dose values of stratigraphic units surfaced in Behramkale (Çanakkale) Zeytinli (Edremit-Balıkesir) section of Kaz Mountains. Journal of Turkısh Chemical Society Section A: Chemistry. 7(1). 207214.

[21] Karataşlı M.(2018); Hatay ve Çevresinde Çevresel Gama Radyasyon Ölçümü. Afyon Kocatepe Üniversitesi Fen ve Mühendislik Bilimleri Dergisi. 780-785. 